\title{
KUALITAS FISIK DAN KIMIA JERAMI JAGUNG YANG DIFERMENTASI DENGAN Trichoderma harzianum
}

\author{
The Physical and Chemical Quality of Maize Straw Fermentation with \\ Trichoderma Harzianum \\ Siti Nur Anisah ${ }^{1)}$, Siti Chuzaemi ${ }^{2)}$ \\ ${ }^{1)}$ Student of the Faculty of Animal Science, University of Brawijaya, East Java, Indonesia, 65145 \\ ${ }^{2)}$ Lecturer at the Faculty of Animal Science, University of Brawijaya, East Java, Indonesia, 65145 \\ E-mail: siti.anisah1999@gmail.com
}

\begin{abstract}
ABSTRAK
Riset dilakukan untuk mengetahui dan mengevaluasi pengaruh fermentasi jerami jagung dengan Trichoderma harzianum pada inkubasi tertentu terhadap kualitas fisik (aroma, warna, tekstur) dan kualitas kimia (analisis proksimat). Metode yang digunakan dalam penelitian ini adalah percobaan laboratorium dengan menggunakan Rancangan Acak Lengkap (RAL) 6 perlakuan dan 3 kali ulangan. Perlakuan terdiri dari P0 (jerami jagung tanpa fermentasi), P1 (jerami jagung $+6 \%$ Trichoderma harzianum inkubasi 24 jam), P2 (jerami jagung $+6 \%$ Trichoderma harzianum inkubasi 48 jam), P3 (jerami jagung $+6 \%$ Trichoderma harzianum inkubasi 72 jam), P4 (jerami jagung $+6 \%$ Trichoderma harzianum inkubasi 96 jam), P5 (jerami jagung $+6 \%$ Trichoderma harzianum inkubasi 120 jam). Data dianalisis dengan menggunakan analysis of variance (ANOVA) dan dilanjutkan dengan Uji Jarak Berganda Duncan (UJBD). Hasil analisis statistik terhadap nilai kandungan bahan kering, bahan organik, protein kasar dan serat kasar menunjukkan perbedaan yang sangat nyata $(\mathrm{P}<0,01)$. Berdasarkan hasil penelitian dapat disimpulkan bahwa fermentasi jerami jagung dengan Trichoderma harzianum pada lama inkubasi yang berbeda mempengaruhi kualitas fisik dan meningkatkan kandungan nutrisi.
\end{abstract}

Kata Kunci: Jerami jagung, lama inkubasi, Trichoderma harzianum

How to Cite:

Anisah, S. N., \& Chuzaemi, S. (2021). Kualitas Fisik dan Kimia Jerami Jagung yang Difermentasi dengan Trichoderma Harzianum. Jurnal Nutrisi Ternak Tropis 4 (2) 93-102
*Corresponding author:

Siti Nur Anisah

Email: siti.anisah1999@gmail.com

Faculty of Animal Science, University of Brawijaya, East Java, Indonesia, 65145 


\section{ABSTRACT}

The aim of this research was to investigate the effect of maize straw fermentation with Trichoderma harzianum at different incubation times towards physical (smell, colour, texture) and chemical quality (proximate analysis). The method used in this research was laboratory experiment with 6 treatments and 3 replications. The 6 treatments were PO (maize straw without fermentation), P1 (maize straw + Trichoderma harzianum $6 \%$ fermented for 24 hours), $P 2$ (maize straw + Trichoderma harzianum 6\% fermented for 48 hours), P3 (maize straw + Trichoderma harzianum 6\% fermented for 72 hours), P4 (maize straw + Trichoderma harzianum 6\% fermented for 96 hours), P5 (maize straw + Trichoderma harzianum 6\% fermented for 120 hours). Data were analyzed using ANOVA of Completely Randomized Design (CRD) and continued by Duncan's Multiple Range Test (DMRT). The result of this research showed that physical quality characteristics of maize straw fermentation with Trichoderma harzianum at different incubation times produce brown colour, sour smell and smooth texture. The result of the proximate analysis showed that the effect of maize straw fermentation with Trichoderma harzianum at different incubation times had highly significant effect $(P<0,01)$ on dry matter, organic matter, crude protein and crude fiber content. The best chemical quality at fermented for 48 hours is the $42.11 \%$ dry matter, $76.43 \%$ organic matter, $10.17 \%$ crude protein, $13.33 \%$ crude fiber. It can be concluded that maize straw fermentation with Trichoderma harzianum at different incubation times can give affects for physical quality and increase nutrient content. The suggestions for the next research needs to be carried out on the digestibility of Trichoderma harzianum addition in fermentation of maize straw (in vivo).

Keywords: Incubation time, maize straw, Trichoderma harzianum

\section{PENDAHULUAN}

Pakan utama ternak ruminansia berupa hijauan yang menjadi sumber energi bagi ternak, oleh karena itu hijauan harus selalu tersedia. Namun, ketersediaan pakan hijauan yang tidak stabil sepanjang tahun akibat permasalahan lahan dan perubahan musim menjadi masalah yang sering dialami peternak dalam menyediakan pakan. Peternak biasanya menggunakan limbah pertanian untuk diberikan kepada ternak untuk menutupi kekurangan hijauan. Klasifikasi kelas bahan pakan ternak menurut Widodo (2017) yaitu salah satu hijauan kering untuk bahan pakan ternak berupa jerami. Jerami jagung adalah salah satu sisa tanaman pertanian yang banyak tersedia pada saat musim panen sehingga jerami jagung dapat digunakan sebagai bahan pakan ternak. Trisnadewi, Cakra dan Suarna (2017) menyatakan jerami jagung mempunyai kandungan nutrisi rendah dan kecernaan rendah konsumsi serat kasar dalam jumlah kecil memiliki manfaat bagi ternak ruminansia salah satunya yaitu sebagai makanan, namun apabila kandungan serat kasar dalam bahan pakan terlalu banyak dapat menyebabkan kecernaan serat kasar yang rendah. Sjofjan, dkk. (2019) menyatakan bahwa serat kasar yang terlalu tinggi didalam bahan pakan yang diberikan untuk ternak dapat memberikan dampak negatif bagi ternak karena zat makanan lain yang lebih bermanfaat menjadi sedikit kegunaannya karena serat kasar sukar untuk dicerna sehingga pakan tertinggal di dalam rumen lebih lama dan ternak hanya kenyang serat kasar. Bahan pakan jerami jagung dapat ditingkatkan kualitas nutrisinya dengan teknologi fermentasi. Fermentasi dapat meningkatkan kandungan nutrisi karena mikroorganisme dapat mendegradasi serat kasar, menurunkan kadar lignin dan senyawa anti nutrisi (Haq, dkk. 2018; Rihadini, Mukodiningsih dan Sumarsih. 2017).

Oleh karena itu, perlu dilakukan kajian untuk mengetahui pengaruh fermentasi jerami jagung dengan pemberian 
Trichoderma harzianum pada waktu inkubasi tertentu dan parameter tertentu.

\section{MATERI DAN METODE}

\section{Materi penelitian}

Jerami jagung, Trichoderma harzianum, TOP Mix, Dedak

\section{Metode penelitian}

Metode penelitian ini adalah percobaan di laboratorium dengan menggunakan Rancangan Acak Lengkap (RAL) 6 perlakuan dan 3 kali ulangan. Perlakuan yang dilakukan dalam penelitian ini adalah sebagai berikut:

$\mathrm{P} 0=$ Jerami jagung tanpa fermentasi (kontrol)

$\mathrm{P} 1=$ Jerami jagung $+6 \%$ Trichoderma harzianum (inkubasi 24 jam)

$\mathrm{P} 2=$ Jerami jagung $+6 \%$ Trichoderma harzianum (inkubasi 48 jam)

$\mathrm{P} 3=$ Jerami jagung $+6 \%$ Trichoderma harzianum (inkubasi 72 jam)

$\mathrm{P} 4=$ Jerami jagung $+6 \%$ Trichoderma harzianum (inkubasi 96 jam)

P5 $=$ Jerami jagung $+6 \%$ Trichoderma harzianum (inkubasi 120 jam)

\section{Prosedur pembuatan fermentasi jerami jagung}

Jerami jagung dikeringkan dibawah sinar matahari hingga kandungan air mencapai 60\% (Semaun, 2013)

1. Jerami jagung kering yang sudah dipotong dengan ukuran \pm 2 sampai 3 cm disiapkan sebanyak 2000gram dan ditambahkan aquadest sebanyak $500 \mathrm{ml}$. Kukus selama 30 menit, setelah itu didinginkan

2. Dedak sebanyak 500 gram dan air 300 ml (5:3) digunakan sebagai media inokulum Trichoderma harzianum (Saifudin, 2020) dan kukus selama 30 menit, setelah itu didinginkan.

3. Masukkan ke dalam plastik klip dan dibiarkan terbuka

4. Inokulan Trichoderma harzianum diambil dengan kawat ose bulat kemudian dicampur dengan campuran dedak dan air lalu diinkubasi selama 4 hari pada suhu kamar.

5. Siapkan mineral TOP mix 100 gram yang sudah dicampur dengan air $150 \mathrm{ml}$ (Saifudin, 2020)

6. Campur jerami jagung sebanyak 100 gram, mineral TOP Mix $10 \mathrm{ml}$ dan inokulum Trichoderma harzianum $6 \%$ untuk setiap perlakuan

7. Masukkan ke dalam plastik klip dan diinkubasi selama 24, 48, 72, 96, 120 jam dalam kondisi anaerob
8. Dikeringkan suhu $60^{\circ} \mathrm{C}$ selama 24 jam dan digrinding.

\section{Variabel pengamatan}

Variabel yang diamati dalam penelitian ini adalah aroma, warna, tekstur, Analisis proksimat dilakukan untuk mengetahui kandungan bahan kering, bahan organik, protein kasar, serat kasar (Sjofjan et al., 2021).

\section{Analisis data}

Data yang dikumpulkan kemudian ditabulasi dan di kalkuasi menggunakan bantuan perangkat lunak menggunakan analisis ragam (anova) dari rancangan acak lengkap (RAL) perbedaan antar perlakuan di uji menggunakan uji jarak berganda duncan. (Sudarwati, Natsir dan Nurgiartiningsih. 2019).

\section{HASIL DAN PEMBAHASAN}

\section{Kualitas fisik fermentasi jerami jagung}

Hasil analisis aroma, warna dan tekstur ditampilkan pada Tabel 1.

\section{Pengaruh perlakuan terhadap aroma}

Hasil analisis statistik pada Tabel 1. menunjukkan bahwa fermentasi jerami jagung dengan Trichoderma harzianum pada lama inkubasi yang berbeda terhadap kualitas fisik aroma memberikan pengaruh yang berbeda sangat nyata $(\mathrm{P}<0,01)$. Hasil uji Jarak Berganda Duncan memberikan hasil bahwa nilai aroma tertinggi pada P5 (120 jam). 
Perlakuan fermentasi jerami jagung terhadap karakteristik aroma berdasarkan seluruh data panelis didapatkan bahwa semakin lama waktu inkubasi menyebabkan aroma jerami jagung berubah dari aroma khas jerami menjadi aroma asam sehingga dapat meningkatkan palatabilitas ternak, hal tersebut diduga karena proses fermentasi dapat mengubah aroma, warna dan tekstur dari suatu bahan pakan menjadi lebih disukai ternak. Hal tersebut sesuai dengan pernyataan Alvianto, Muhtarudin dan Erwanto (2019) menyatakan bahwa palatabilitas bahan pakan silase limbah sayuran tanpa perlakuan memiliki tingkat palatabilitas terendah apabila dibandingkan dengan perlakuan silase sebab hewan ternak akan memilih pakan yang memiliki aroma asam dan wangi. Hasil penelitian perlakuan P5 dengan lama inkubasi 120 jam memiliki dominasi rata-rata aroma asam dibandingkan perlakuan lainnya. Hal tersebut sesuai dengan pernyataan Basri, Syamsuddin dan Daning (2019) bahwa hasil penelitian kulit kopi dengan penambahan Trichoderma harzianum menghasilkan aroma asam yang disebabkan karena aktivitas mikroba anaerob sehingga terjadi perubahan aroma menjadi asam pada saat penyimpanan. Aglazziyah, Ayuningsih dan Khairani (2020) bahwa aroma asam yang dihasilkan dari proses fermentasi dikarenakan kandungan asam laktat yang terdapat pada silase.

Tabel 1. Kualitas fisik fermentasi jerami jagung

\begin{tabular}{cccc}
\hline \multirow{2}{*}{ Perlakuan } & \multicolumn{3}{c}{ Kualitas Fisik } \\
\cline { 2 - 4 } & Aroma & Warna & Tekstur \\
\hline P0 & $2,13^{a} \pm 0,34$ & $2,64^{a} \pm 0,61$ & $1,62^{a} \pm 0,49$ \\
P1 & $2,67^{b} \pm 0,90$ & $3,11^{b} \pm 0,61$ & $2,29^{b} \pm 0,59$ \\
P2 & $3,11^{b c} \pm 0,98$ & $3,33^{b c} \pm 0,48$ & $2,87^{c} \pm 0,69$ \\
P3 & $3,22^{c d} \pm 0,97$ & $3,60^{c d} \pm 0,50$ & $3,22^{d} \pm 0,64$ \\
P4 & $3,64^{d e} \pm 0,74$ & $3,76^{d} \pm 0,43$ & $3,64^{e} \pm 0,48$ \\
P5 & $3,76^{e} \pm 0,65$ & $3,84^{d} \pm 0,37$ & $3,71^{e} \pm 0,46$ \\
\hline Keterangan & $a b c d e$ Superskrip yang berbeda pada kolom yang & sama menunjukkan \\
& perbedaan sangat nyata $(\mathrm{P}<0,01)$ &
\end{tabular}

\section{Pengaruh perlakuan terhadap warna}

Berdasarkan hasil analisis statistik pada Tabel 1. diketahui bahwa fermentasi jerami jagung dengan Trichoderma harzianum pada lama inkubasi yang berbeda terhadap karakteristik fisik warna memberikan pengaruh yang berbeda sangat nyata $(\mathrm{P}<0,01)$. Hasil uji Jarak Berganda Duncan memberikan hasil bahwa nilai warna tertinggi pada P5 (120 jam) dan warna terendah pada P0 (kontrol). Perlakuan fermentasi jerami jagung terhadap karakteristik fisik warna berdasarkan seluruh data panelis didapatkan bahwa lama inkubasi dapat merubah warna jerami jagung kuning hingga menjadi coklat. Warna jerami jagung tanpa perlakuan didominasi warna coklat muda. Perlakuan fermentasi jerami jagung pada P1 (24 jam) dan P2 (48 jam) berturut-turut 3,11 dan 3,33 hal tersebut cukup baik dikarenakan warna yang dihasilkan tidak jauh berbeda seperti warna awal tanpa perlakuan yaitu coklat muda. Hal tersebut sesuai dengan pernyataan Utomo, Budhi dan Astuti (2013) bahwa kualitas fisik warna bahan pakan yang baik adalah yang mendekati warna aslinya yaitu warna saat pembuatan pakan (warna bahan baku awal tanpa perlakuan).

Berdasarkan hasil analisis statistik diketahui bahwa fermentasi jerami jagung dengan Trichoderma harzianum pada lama inkubasi yang berbeda perlakuan P3 (72 jam), P4 (96 jam), P5 (120 jam) berturutturut $3,60,3,76,3,84$ yaitu didominasi warna coklat apabila dibandingkan dengan jerami jagung tanpa perlakuan. Perubahan warna tersebut diduga karena tingginya suhu pada saat proses fermentasi sehingga mengalami perubahan dari warna coklat 
muda menjadi coklat. Candrasari, Fitria dan Hindratiningrum (2019) menyatakan bahwa hasil penelitian terdapat perubahan warna pada janggel jagung yaitu kuning menjadi coklat gelap yang disebabkan karena adanya proses penguraian bahan organik selama proses fermentasi sehingga terjadinya suasana panas yang menyebabkan proses maillard atau browning reaction. Proses pengukusan, lama fermentasi dan kondisi penyimpanan anaerob pada penelitian fermentasi jerami jagung mengakibatkan terdapatnya air yang keluar dari bahan pakan kemungkinan mempengaruhi warna dari bahan pakan (Retnani, dkk (2008) dalam Solihin, Muhtarudin dan Sutrisna (2015).

\section{Pengaruh perlakuan terhadap tekstur}

Berdasarkan hasil analisis statistik pada Tabel 1. diketahui bahwa fermentasi jerami jagung dengan Trichoderma harzianum pada lama inkubasi yang berbeda terhadap karakteristik fisik tekstur memberikan pengaruh yang berbeda sangat nyata $(\mathrm{P}<0,01)$. Hasil uji Jarak Berganda Duncan memberikan hasil bahwa nilai tekstur tertinggi pada P5 (120 jam) dan tekstur terendah pada P0 (kontrol). Perlakuan fermentasi jerami jagung terhadap karakteristik fisik tekstur berdasarkan seluruh data panelis didapatkan bahwa lama inkubasi dapat merubah tekstur jerami jagung sangat kasar menjadi sangat halus. Hal tersebut sesuai dengan pernyataan Christi, Rochana dan Hernaman (2018) bahwa fermentasi yaitu pengolahan bahan pakan secara aerob maupun anaerob dengan menggunakan mikroorganisme yang berfungsi untuk memecah senyawa kompleks menjadi senyawa sederhana sehingga menghasilkan kualitas fisik seperti aroma, warna, rasa dan tekstur lebih baik serta dapat meningkatkan palatabilitas.

Berdasarkan hasil analisis statistik penelitian kualitas fisik tekstur diketahui bahwa perlakuan terbaik pada P2 (48 jam) yaitu 2,87 dikarenakan tekstur tidak terlalu kasar dan tidak terlalu lunak ataupun lembek. Hal tersebut sesuai dengan pernyataan Saifudin (2020) bahwa fermentasi yang berkualitas baik memiliki tekstur segar yang masih seperti bahan pakan awal sebelum diberi perlakuan sehingga perlakuan terbaik fermentasi eceng gondok dengan tekstur yang mendekati hasilnya.

Berdasarkan hasil penelitian diketahui bahwa terjadi perubahan tekstur pada jerami jagung menjadi sangat halus pada perlakuan P3 (72 jam), P4 (96 jam) dan P5 (120 jam) dikarenakan adanya aktivitas enzim sehingga mampu memecah ikatan yang ada pada bahan pakan. Hal tersebut sesuai dengan pernyataan Reksohadiprodjo (1988) dalam Puspitasari, Fathul dan Tantalo (2014) bahwa tanaman yang melalui proses fermentasi akan mengalami perubahan yang disebabkan karena proses respirasi anaerob yang masih berlangsung selama oksigen tersedia hingga sampai gula tanaman habis kemudian $\mathrm{CO}_{2}$ dan suhu mengalami kenaikan yang mengakibatkan warna dan tekstur tanaman berubah.

\section{Kualitas kimia fermentasi jerami jagung}

Hasil analisis bahan kering, bahan organik, protein kasar, serat kasar ditampilkan pada Tabel 2.

Hasil analisis ragam bahan kering pada Tabel 2. menunjukkan bahwa fermentasi jerami jagung dengan Trichoderma harzianum pada lama inkubasi yang berbeda memberikan pengaruh yang sangat nyata $(\mathrm{P}<0,01)$. Prosedur penelitian fermentasi jerami jagung dilakukan penyiraman jerami jagung dengan aquadest sebelum dikukus yang berfungsi untuk melayukan jerami jagung, hal tersebut sesuai dengan pernyataan Kuikui, et al (2014) menyatakan bahwa kelembaban jerami gandum awal $10 \%$ diubah menjadi $60 \%$ dengan penyemprotan air suling dikarenakan kadar air bahan silase berperan penting sehingga mempengaruhi proses fermentasi bahan pakan dikarenakan bakteri asam laktat membutuhkan kelembaban untuk proses metabolisme dan pengangkutan oksigen selama proses fermentasi.

Hasil penelitian menunjukkan bahwa lama fermentasi dapat menyebabkan produk mengeluarkan air yang berdampak pada 
penurunan kandungan bahan kering sehingga semakin lama waktu fermentasi maka menunjukkan penurunan bahan kering dengan sangat nyata $(\mathrm{P}<0,01)$. Hanum dan Usman (2011) menyatakan bahwa penurunan kandungan bahan kering diduga karena adanya degradasi dinding sel oleh mikroba pada ikatan lignin dengan selulosa ataupun dengan hemiselulosa yang didegradasi oleh mikroba selama proses penyimpanan bahan pakan. Kandungan bahan kering yang hilang pada saat proses fermentasi juga dipengaruhi oleh spesies mikroba yang dominan dan substrat yang difermentasi sehingga penurunan kandungan bahan kering pada penelitian fermentasi jerami jagung pada perlakuan P5 (120 jam) dikarenakan substrat dimanfaatkan oleh mikroba untuk bahan baku pertumbuhan dan mengalami proses respirasi sehingga kandungan air meningkat. Astuti, Rofiq dan Nurhaita (2017) juga menambahkan bahwa penurunan bahan kering pada proses fermentasi dikarenakan mikroba menggunakan nutrien yang berasal dari substrat.

Tabel 2. Kualitas kimia fermentasi jerami jagung

\begin{tabular}{ccccc}
\hline \multirow{2}{*}{ Perlakuan } & \multicolumn{5}{c}{ Kualitas Kimia } \\
\cline { 2 - 5 } & $\mathrm{BK}(\%)$ & $\mathrm{BO}^{*}(\%)$ & $\mathrm{PK}^{*}(\%)$ & $\mathrm{SK}^{*}(\%)$ \\
\hline P0 & $73,74^{c} \pm 3,07$ & $77,59^{b c} \pm 0,44$ & $5,31^{a} \pm 0,23$ & $27,86^{c} \pm 0,97$ \\
$\mathrm{P} 1$ & $43,74^{b} \pm 1,97$ & $74,19^{a} \pm 1,95$ & $9,10^{b} \pm 0,58$ & $13,88^{b} \pm 0,76$ \\
$\mathrm{P} 2$ & $42,11^{a b} \pm 2,54$ & $76,43^{a b} \pm 2,00$ & $10,17^{b} \pm 0,21$ & $13,33^{a b} \pm 0,72$ \\
P3 & $41,03^{a b} \pm 2,19$ & $77,92^{b c} \pm 0,95$ & $5,86^{a} \pm 0,68$ & $12,02^{a} \pm 0,80$ \\
P4 & $36,77^{a b} \pm 5,00$ & $80,97^{c d} \pm 0,76$ & $5,89^{a} \pm 0,73$ & $12,59^{a b} \pm 0,58$ \\
P5 & $36,29^{a} \pm 1,32$ & $82,01^{d} \pm 0,39$ & $5,74^{a} \pm 0,10$ & $13,82^{b} \pm 0,17$ \\
\hline Keterangan & $*$ Berdasarkan 100\% BK & & \\
& abcd Superskrip yang berbeda pada kolom yang sama menunjukkan
\end{tabular}

Hasil analisis ragam bahan organik pada Tabel 2. menunjukkan bahwa fermentasi jerami jagung dengan Trichoderma harzianum pada lama inkubasi yang berbeda memberikan pengaruh yang sangat nyata $(\mathrm{P}<0,01)$. Hasil penelitian menunjukkan bahwa kandungan bahan organik tertinggi terjadi pada perlakuan P5 yaitu sebesar 82,01\% dan kandungan bahan organik terendah terjadi pada perlakuan P1 yaitu sebesar $74,19 \%$. Perbedaan kandungan bahan organik antara P0 dan P1 dimungkinkan disebabkan karena substrat dimanfaatkan oleh mikroba untuk aktivasi dan pertumbuhan.

Berdasarkan hasil penelitian fermentasi jerami jagung diketahui bahwa pada perlakuan P5 (120 jam) kandungan bahan organik cenderung meningkat. Perubahan kandungan tersebut dimungkinkan karena pada saat proses fermentasi menunjukkan adanya aktivitas mikroba yaitu kapang Trichoderma harzianum yang bekerja terhadap jerami jagung (Astuti, dkk 2017). Hasil penelitian yang dilakukan oleh Kasmiran (2011) yaitu fermentasi jerami padi dengan mikroorganisme lokal membuktikan bahwa lama waktu fermentasi menyebabkan semakin turunnya kandungan abu pada jerami yang disebabkan karena silika, bagian dari abu, dapat larut dalam larutan basa sehingga dapat menurunkan kandungan abu karena abu terdiri dari silika dan mineral lainnya seperti garam organik. Kadar bahan organik yang mengalami peningkatan dimungkinkan oleh peningkatan protein kasar dikarenakan bakteri selulolitik mengalami perkembangbiakan (Arif dan Lamid, 2014). 
Berdasarkan hasil analisis ragam protein kasar pada Tabel 2. menunjukkan bahwa fermentasi jerami jagung dengan Trichoderma harzianum pada lama inkubasi yang berbeda memberikan pengaruh yang sangat nyata $(\mathrm{P}<0,01)$. Hasil penelitian menunjukkan bahwa kandungan protein kasar tertinggi terjadi pada perlakuan P2 (48 jam) yaitu sebesar 10,17 \% dan kandungan protein kasar terendah terjadi pada perlakuan P0 (kontrol) yaitu sebesar 5,31\%. Berdasarkan hasil penelitian diketahui bahwa lama inkubasi menyebabkan pertumbuhan Trichoderma harzianum bekerja optimal pada perlakuan P2 (48 jam) pada proses fermentasi jerami jagung sehingga terjadinya kenaikan kandungan protein kasar akibat dari pemecahan komponen lignoselulosa di dalam bahan pakan jerami jagung oleh aktivitas kapang. Hal tersebut sesuai dengan pernyataan Febrina, Khairunnisa dan Febriyanti (2020) bahwa terjadinya kenaikan kandungan protein kasar pada penelitian jerami jagung disebabkan karena lama proses inkubasi mengalami penurunan dan kandungan protein kasar meningkat. Indariyanti dan Rakhmawati (2013) juga menambahkan bahwa kandungan protein yang meningkat dikarenakan terjadinya proses sintesis protein oleh kapang. Lebih lanjut dijelaskan bahwa pertumbuhan kapang yang semakin banyak maka kandungan protein kasar akan meningkat dikarenakan peningkatan miselium kapang pada substrat.

Berdasarkan hasil penelitian diketahui bahwa pada perlakuan P3 (72 jam), P4 (96 jam), P5 (120 jam) kandungan protein kasar mengalami penurunan yakni berturut-turut menjadi $5,86 \%, 5,89 \%$ dan $5,74 \%$, apabila dibandingkan dengan P1 (24 jam) dan P2 (48 jam) yang diduga karena kapang yang tersedia menurunkan kandungan protein kasar pada jerami jagung. Menurut Mirwandhono, dkk (2006) dalam Rohmawati, Djunaidi dan Widodo (2015) bahwa perkembangan mikroba sudah mencapai fase pertumbuhan eksponensial sehingga laju pertumbuhan populasinya sudah mulai mengalami penurunan.
Pernyataan tersebut diperkuat oleh Wang, et al (1979) dalam Mirzah dan Muis (2015) bahwa kandungan protein kasar yang rendah disebabkan karena fase siklus mikroorganisme mencapai fase stationeri. Kandungan protein kasar yang mengalami penurunan terjadi pada penelitian yang dilakukan oleh Hadist, Titin dan Puspitasari (2018) yaitu fermentasi bonggol pisang menggunakan Trichoderma harzianum disebabkan jumlah mikroorganisme sampai level tertentu menyebabkan simbiosis parasititsme terjadi, dimana protein tersebut masih mengalamai degradasi.

\section{Pengaruh perlakuan terhadap serat kasar}

Berdasarkan hasil analisis ragam serat kasar pada Tabel 2. menunjukkan bahwa fermentasi jerami jagung dengan Trichoderma harzianum pada lama inkubasi yang berbeda memberikan pengaruh yang sangat nyata $(\mathrm{P}<0,01)$. Hasil penelitian menunjukkan bahwa kandungan serat kasar terendah terjadi pada perlakuan P3 (72 jam) yaitu sebesar 12,02\% dan kandungan serat kasar tertinggi terjadi pada perlakuan P0 (kontrol) yaitu sebesar 27,86\%. Berdasarkan hasil penelitian tersebut diketahui bahwa fermentasi jerami jagung dengan Trichoderma harzianum pada lama inkubasi yang berbeda mampu menurunkan kandungan serat kasar yang dimungkinkan akibat kemampuan mikroba menghasilkan enzim pemecah 3 komponen utama dinding sel tumbuhan yaitu selulosa, lignin dan hemiselulosa. Mikroorganisme selulolitik dapat digunakan untuk meningkatkan kandungan nutrisi bahan pakan untuk ternak ruminansia melalui proses fermentasi sehingga dapat meningkatkan kecernaan ternak. Somchart, et al (2019) menambahkan bahwa fungi selulolitik yang terdapat pada Trichoderma viride mampu mendegradasi bahan lignoselulosa secara selektif dengan mendegradasi komponen selulosa sehingga dapat meningkatkan nilai nutrisi bahan pakan. Penelitian yang dilakukan oleh Udding, Nohong dan Munir (2014) yaitu fermentasi rumput gajah dan tumpi jagung dengan Trichoderma $s p$. 
mampu menurunkan serat kasar dikarenakan Trichoderma $s p$. mampu merubah komposisi zat makanan terutama protein kasar dan serat kasar. Lebih lanjut dijelaskan bahwa penambahan Trichoderma $s p$. dikarenakan kapang tersebut mempunyai kemampuan untuk menghasilkan enzim selulase sehingga dapat mendegradasi selulosa pada bahan pakan (Adli dan Sjofjan, 2021).

Berdasarkan hasil penelitian diketahui bahwa pada perlakuan P4 (96 jam) dan P5 (120 jam) kandungan serat kasar mengalami kenaikan menjadi $12,59 \%$ dan $13,82 \%$ tetapi masih rendah apabila dibandingkan dengan P0 (kontrol). Penelitian fermentasi limbah tauge dengan menggunakan Trichoderma harzianum yang dilakukan oleh Mawarni, Mukodiningsih dan Prasetyo (2017) mengalami kenaikan serat kasar dikarenakan kapang masih terus tumbuh dan berkembang sehingga hifa kapang yang dihasilkan juga bertambah mengakibatkan kandungan serat kasar relatif sama karena kapang tersebut menyumbangkan hifa pada medium bahan pakan.

\section{KESIMPULAN}

Fermentasi jerami jagung menggunakan trichoderma harzianum pada lama inkubasi yang berbeda mempengaruhi kualitas jerami jagung yaitu semakin lama fermentasi maka menghasilkan aroma asam, warna coklat dan bertekstur sangat halus. Selain itu, kualitas kimia jerami jagung juga dipengaruhi oleh lama fermentasi. Fermentasi pada perlakuan P2 (lama inkubasi 48 jam) yang memiliki kandungan Protein Kasar (PK) 10,17 \%, Serat Kasar (SK) 13,33\% merupakan perlakuan terbaik.

\section{DAFTAR PUSTAKA}

Al-Arif, M. A., \& Lamid, M. (2014). kualitas pakan ruminansia yang difermentasi bakteri selulolitik actinobacillus sp. Acta VETERINARIA Indonesiana, 2(1), 12-16. https://doi. org/10.29244/avi.2.1.12-16
Alvianto, A., Muhtarudin, M., \& Erwanto, E. (2015). Pengaruh penambahan berbagai jenis sumber karbohidrat pada silase limbah sayuran terhadap kualitas fisik dan tingkat palatabilitas silase. Jurnal Ilmiah Peternakan Terpadu, 3(4), 196-200. https://doi. org/10.23960/jipt.v3i4.1097

Astuti, T., Rofiq, M. N., \& Nurhaita, N. (2017). Evaluasi kandungan bahan kering, bahan organik dan protein kasar pelepah sawit fermentasi dengan penambahan sumber karbohidrat. Jurnal Peternakan, 14(2), 42-47. https: //doi.org/10.24014/jupet.v14i2.4247

Basri, H., Syamsuddin, A., \& Daning, D. R. A. (2019). Kualitas organoleptik dan nilai $\mathrm{pH}$ Kulit kopi yang difermentasi dengan penambahan level trichoderma sp. yang Berbeda. Jurnal Ilmu Peternakan Terapan, 3(1), 1-5. https:// doi.org/10.25047/jupiter.v3i1.1512

Candrasari, D. P., Fitria, R., \& Hindratiningrum, N. (2019). Pengaruh perlakuan amoniasi fermentasi (amofer) terhadap kualitas fisik janggel jagung. Jurnal Ilmiah Ilmu-Ilmu Peternakan, 22(2), 117-123. https://doi.org/10.224 37/jiiip.v22i2.8352

Christi, R. F. (2019). Kualitas fisik dan palatabilitas konsentrat fermentasi dalam ransum kambing perah peranakan ettawa. Jurnal Ilmu Ternak Universitas Padjadjaran, 18(2), 121125. https://doi.org/10.24198/jit.v18i2 .19461

Febrina, D., Khairunnisa, N., \& Febriyanti, R. (2020). Pengaruh lama pemeraman dan metode pengolahan terhadap kualitas fisik dan kandungan nutrisi jerami jagung. Jurnal Agripet, 20(2), 160-167. https://doi.org/10.17969/agr ipet.v20i2.16837

Hadist, I. (2019). The usage of fungi trichoderma harzianum and aspergillus niger on fermentation of bananas corm (Musa sp.). Jurnal Peternakan Nusantara, 4(2), 67-74. https://doi. org/10.30997/jpnu.v4i2.1536

Hansa, A., Ayuningsih, B., \& Lizah, K. (2020). 
Pengaruh penggunaan dedak fermentasi terhadap kualitas fisik dan $\mathrm{pH}$ silase rumput gajah (Pennisetum purpureum). Jurnal Nutrisi Ternak Tropis Dan Ilmu Pakan, 2(3), 156-165.

Hanum, Z., \& Usman, Y. (2011). Analisis proksimat amoniasi jerami padi dengan penambahan isi rumen. Jurnal Agripet, 11(1), 39-44. https://doi.org/ 10.17969/agripet.v11i1.653

Indariyanti, N., \& Rakhmawati. (2013). Peningkatan kualitas nutrisi limbah kulit buah kakao dan daun lamtoro melalui fermentasi sebagai basis protein pakan ikan nila. Jurnal Penelitian Pertanian Terapan, 13(2), 108-115. https://doi.org/10.25181/jp pt.v13i2.173

Kasmiran, A. (2011). Pengaruh lama fermentasi jerami padi dengan mikroorganisme lokal terhadap kandungan bahan kering, bahan organik, dan abu. LENTERA, 11(1), 48-52.

Mawarni, D., \& Mukodiningsih, S. (2017). Komposisi proksimat limbah tauge yang difermentasi menggunakan Trichoderma harzianum. In Buletin Ilmu-Ilmu

Mirzah, M., \& Muis, H. (2015). Peningkatan kualitas nutrisi limbah kulit ubi kayu melalui fermentasi menggunakan bacillus amyloliquefaciens. Jurnal Peternakan Indonesia (Indonesian Journal of Animal Science), 17(2), 131-142. https://doi.org/10.25077/jpi. 17.2.131-142.2015

Ni, K., Wang, Y., Pang, H., \& Cai, Y. (2014). Effect of cellulase and lactic acid bacteria on fermentation quality and chemical composition of wheat straw silage. American Journal of Plant Sciences, 05(13), 1877-1884. https://doi.org/10.4236/ajps.2014.513 201

Puspitasari, F., Fathul, F., \& Tantalo, S. (2014). Pengaruh dosis urea dalam amoniasi daun nenas varietas smooth cayene terhadap kadar bahan kering, abu dan serat kasar. Jurnal Ilmiah
Peternakan Terpadu, 2(3), 53-61. https://doi.org/http://dx.doi.org/10.23 960/jipt.v2i3.p\%25p

Rihadini, R. A., Mukodiningsih, S., \& Sumarsih, S. (2017). Kualitas fisik organoleptik limbah tauge kacang hijau yang difermentasi menggunakan trichoderma harzianum dengan level yang berbeda. Jurnal Ilmiah Peternakan Terpadu, 5(2), 28-32. https: //doi.org/10.23960/jipt.v5i2.p28-32

Rohmawati, D., Djunaidi, I., \& Widodo, E. (2015). Nilai nutrisi tepung kulit ari kedelai dengan level inokulum ragi tape dan waktu inkubasi berbeda. TERNAK TROPIKA Journal of Tropical Animal Production, 16(1), 30-33. https://doi.org/10.21776/ub.jta pro.2015.016.01.5

Saifudin, A. M. (2020). Kualitas Fisik Dan Kimia Daun Eceng Gondok (Eichhornia crassipes) Yang Difermentasi Dengan Trichoderma harzianum Pada Lama Inkubasi Yang Berbeda. University of Brawijaya.

Semaun, R. (2013). Kecernaan in-vitro kombinasi fermentasi jerami jagung dan dedak kasar dengan penambahan aspergillus niger. Jurnal Galung Tropika, 2(2), 97-102.

Sjofjan, O, Natsir, M. H., Chuzaemi, S., \& Hartutik. (2019). Ilmu Nutrisi Ternak Dasar. UB Press.

Sjofjan, Osfar, \& Adli, D. N. (2021). The effect of replacing fish meal with fermented sago larvae (FSL) on broiler performance. Livestock Research for Rural Development, 33(2).

Sjofjan, Osfar, Nur Adli, D., Djunaidi, I., \& Kuncoro, K. (2020). Utilization of biogas liquid waste for starter in the fermentation of rice husk as a potential feed for poultry. Animal Production, 22(1), 24-30. https://doi.org/10.208 84/1.jap.2020.22.1.38

Solihin, S., Muhtarudin, M., \& Sutrisna, R. (2015). Pengaruh lama penyimpanan terhadap kadar air kualitas fisik dan sebaran jamur wafer limbah sayuran 
dan umbi-umbian. Jurnal Ilmiah Peternakan Terpadu, 3(2), 48-54. https://doi.org/10.23960/jipt.v3i2.767

Somchart, T., Tosawat, A., Choke, S., \& Khanchai, D. (2019). Nutritional composition of maize husk silage generated from solid state fermentation by Trichoderma viride UP01. Pakistan Journal of Botany, 51(6), 2255-2260. https://doi.org/10.3 0848/PJB2019-6(28)

Sudarwati, H., Natsir, M. H., \& Nurgiartiningsih, V. M. A. (2019). Statistika dan Rancangan Percobaan (Penerapan dalam Bidang Peternakan). UB Press.

Trisnadewi, A. A. A. S., Cakra, I. G. L. O., \& Suarna, I. W. (2017). Kandungan nutrisi silase jerami jagung melalui fermentasi pollard dan molases.
Majalah Ilmiah Peternakan, 20(2), 55-59. https://doi.org/10.24843/MIP .2017.v20.i02.p03

Udding, R., Nohong, B., \& Munir. (2014). Analisis kandungan protein kasar (PK) dan serat kasar kombinasi rumput gajah (pennisetum purpureum) dan tumpi jagung yang terfermentasi. Jurnal Galung Tropika, 3(3). https://doi.org/http://dx.doi.org/ 10.31850/jgt.v3i3.94

Utomo, R., Budhi, S. P. S., \& Astuti, I. F. (2013). Pengaruh level onggok sebagai aditif terhadap kualitas silase isi rumen sapi. Buletin Peternakan, 37(3), 173-180. https://doi.org/10.210 59/buletinpeternak.v37i3.3089

Widodo, E. (2017). Ilmu Bahan Pakan Ternak dan Formulasi Pakan Unggas. UB Press. 